\title{
Social Harmony Model within Differences through Educational System
}

\author{
Santi Susanti*, Asep Suryana, Fitri Perdana \\ Faculty of Communication Science, Universitas Padjadjaran, Jatinangor, West Java, Indonesia.
}

\begin{abstract}
This paper aims to reveal the efforts by one elementary school in Garut, SD Bestari utami, in providing quality education to their students without distinguishing their socio-cultural background. Through the principle of equality and togetherness, SD Bestari Utami seeks to harmonize the differences among the students into a unity of Indonesia. The method used in this research is qualitative with phenomenology approach. Data collection is done by in-depth interviews, literature review and on-site observation. The result of the research shows that establishment of Bestari Utami Elementary School as a school that provides educational equity for Sundanese and Chinese children is motivated by the experience of founder and principal Christanti Gomulia who feel how beautiful life is in unity together without discriminating socialculture background. Mutual respect in socio-cultural differences enriched Christanti's soul and mind and she can freely develop her personality in accordance with the cultural background surrounds her. Through the curriculum she designed, SD Bestari Utami directed each of their students to always appreciate the differences and not forget the cultural roots from which they originated, it's Sundanese culture.
\end{abstract}

Keywords: Differences, Togetherness, Harmony, SD Bestari Utami, Cultural Roots

\section{Introduction}

Differences are the human nature, as God created human beings in different, to get to know each other, help each other and live in harmony. Diversity in its various forms is the color of human life, as well as potential to strengthen unity because it can cover each other's handicaps. In unity, life is peaceful and beautiful. Being a Chinese individual or as a Sundanese is a part of life that God has been determined and must be lived by human beings. The apparent differences should not be a trigger for conflict, but rather serve as a collective power by harmonizing differences in togetherness.

School is an environment that can be a reflection of the alignment in the difference. Various differences in it, strived not to collide and cause conflict, but go hand in hand in togetherness. Efforts to align the differences are implemented by Bestari Utami Elementary School in Garut, which applies the principle of togetherness and equality in providing quality education for their students without distinguishing their socio-cultural background.

The school located at Jalan Cimaragas 131, Garut. Its students consist of children of Chinese descent and children of the Sundanese. Based on my observations, the students at SD Bestari Utami looked familiar with each other in the learning activities provided by the teachers, both in class and outside the classroom. Bestari Utami School was founded in 2009 by education practitioner named Christanti Gomulia, to provide education to children according to the characters regardless of their socio-cultural background. She is a Chinese descendant who lived with her parents in the neighborhood of the Sundanese on Jalan Pasundan, Garut Kota. In the neighborhood, Tanti felt not distinguished just because she was of Chinese descent. Her neighbors treated her and his family well. They respect each other and live in harmony in the same environment, even though they are ethnically different.

This paper aims to reveal the efforts made by Christanti through SD Bestari Utami, to provide quality

\footnotetext{
* Corresponding author: santisusanti2202@gmail.com
} 
education to their students without distinguishing their socio-cultural background. Also Christanti's background applies the principle of togetherness and equality in education held at the Bestari Utami school. Through the principle of equality and togetherness, SD Bestari Utami seeks to harmonize the differences that exist in the students themselves into a unity of Indonesia.

\section{Methodology}

This research uses a qualitative with phenomenology approach to express the experience of Christanti in building togetherness in the students and the background of the behavior. Data was collected through in-depth interviews, on-site observation and research-related document review. The Social Action Theory of Max Weber and Alfred Schutz's Theory of Social Phenomenology are used as the basis for analyzing research data. Data analysis using Miles and Huberman[1] analysis techniques, with data reduction, data presentation and verification performed continuously during the research process. The results are presented in the form of a descriptive narrative with detailed explanations and conclusions made inductively.

The informants were Christanti Gomulia, a Chinese descent professional educator who has a dream job to establish a quality school without distinguishing the learner's origin. The informant was selected based on the needs of purposive sampling research[2] .Regarding the number of research subjects, Maxwell in Alwasilah[3] explains that in qualitative research, the number of informants is not a problem. The important is the informant reflects the uniqueness of the background, the individual and the activities.

\section{Discussion}

The result of the studies shows that establishment of Bestari Utami Elementary School as a school that provides educational equity for Sundanese and Chinese children is motivated by the experience of founder and principal Christanti Gomulia who feel how beautiful life is in unity together without discriminating socio-culture background. Mutual respect in socio-cultural differences makes Christanti soul and mind of becoming rich and she can freely develop her personality in accordance with the cultural background that surrounds her.

Bestari Utami can be regarded as a school that implements multicultural education in its students. Multiculturalism education usually has the following characteristics: (1) its purpose to form "human culture" and create "civilized society" (2) the material teaches the noble values of humanity, the values of the nation, and the values (3) democratic methods that appreciate aspects of diversity and cultural diversity of nations and ethnic groups (multiculturalist), (4) its evaluation is determined on the assessment of students' behavior that includes: perception, appreciation, and action against other cultures[4].

Similarly, the pattern of education that runs at SD Bestari Utami Garut. Christanti is trying to make SD Bestari Utami as a child-friendly school. Educational methods that do adapt to the character of the child. With a democratic system, children are trained to have the initiative and creativity in doing the tasks assigned by the teacher.

Through the curriculum she designed, SD Bestari Utami directed each of her students to always appreciate the differences and not forget the cultural roots from which they originated, Sundanese art and culture. Art became the spearhead of education at SD Bestari Utami which is used as a unifying medium for children with different backgrounds. With art, children are educated to be united by harmonizing the instruments they play, in order to create harmonious harmony and comfort to be heard. Christanti, one of the informants, stated:

Our art is amazing, no one can beat it. If not an art, its culinary. This might be a force for our children to come.

The application of Sundanese arts education at Bestari Utami school is part of Chistanti's effort to instill a sense of appreciation for Sundanese culture, so that the students will not forget the cultural roots of their place, Sunda. Christanti further stated:

In my school, 80 percent are Muslim. So, I have a moral obligation. These children are native Sundanese, and the other 20 percent are like me, the descendants of the Chinese physically. But you live in tatar Sunda. For all to know, instilling cultural roots can only start early.

Sundanese cultural values applied through learning gamelan. Many values can be learned from the process of learning gamelan by Bestari Utami students. In the gamelan, every child learns to work harmoniously in the team. When playing the gamelan, students are required to be able to master the emotions and play with all my heart. They also have to focus, because if one plays a musical instrument, it will not create harmony.

Togetherness is also created by Bestari Utami school by holding a colossal show, Kabayan the City Boy, in 2011, which was played by all students of SD Bestari Utami at that time.The play presents Sundanese stories with a packed dialogue in English with Sundanese accents. It happened in 2011. All children are involved, without exception. The performance received extraordinary appreciation from the audience. Tanti felt proud and happy when her protege realized the 
importance of togetherness, especially with people of different cultural backgrounds:

I know that Sundanese does not differentiate. So we also apply it to the children's performance. We've been performing 120 children in a colossal drama. We don't differentiate the children. The stage belongs together. That's beautiful.

The drama involving all of Bestari Utami elementary students has been performed twice, in 2007 and 2009, each attended by 500 and 700 spectators. The drama is dedicated to the community to revive children's interest in Sundanese culture and be served in a 'child's taste' but with a deep mission, which unifies differences among students. The success of this course is very proud of Tanti, because he managed to blend Chinese children with Sundanese in his school in a show that shows how wonderful togetherness and unity that does not consider the differences in ethnicity, religion and economic level.

Slowly but sure, through various cultural arts activities conducted, the children began to appreciate the Sundanese culture taught at SD Bestari Utami, Through art, Tanti seeks to unify the differences between Chinese children with children of Sundanese so that the emerging awareness of togetherness as people Sundanese, who know his identity well. The composition of students divided into 70 percent of Sundanese children and 30 percent of Chinese children, is a fixed benchmark, so that Chinese children want to mingle with their friends who come from the Sundanese.

To keep together, schools apply rules that prohibit children to intimidate other students. The goal is to maintain the harmony of togetherness in the school. The rules on banned bullying are installed in every classroom. In it were written prohibitions against violence against friends. If violated, there are sanctions that have been included in the rule.

Through the various efforts, Tanti hopes, the children know their identity well. Tanti has felt how Sundanese culture has shaped her into a good person and able to appreciate each other. She also determined that her students, both Chinese and Sundanese, should recognize kasundaan and not forget their identity as Sundanese.

Basically, every child needs to play in their life. In any learning needs to play still exist. Therefore, while studying, Bestari Utami school implements the game as one of the learning methods for its students. Through the game, children are trained to work with their peers in solving one problem. They are also required to be able to maintain coordination between the body and mind in answering the questions given through the game.

\section{Conclusion}

Christanti's effort to set up Bestari Utami school that does not distinguish the background of its students is the result of its interpretation of the Sundanese cultural values that do not discriminate against people based on their background. Tanti who felt it since childhood, did not want to see a split because of differences in the background. Through the school she founded, Tanti wanted to unify the differences in order to merge in one unity as a nation of Indonesia, with roots in Sundanese culture. The learning pattern applied at Bestari Utami is an integrated program that directs students to respect each other, regardless of their socio-cultural background. School harmony is expected to be created and applied, as well as to the social aspects of how students learn in the natural environment. like loving nature by throwing garbage in its place, recycling waste, and so on. When at school, they have become a unit as the elementary school children of Bestari Utami, who must obey the rules set by the school. The dedication to providing quality education to students encourages teachers to apply a wholeheartedly determined curriculum with high creativity to encourage students to be a generation that respects differences, loves togetherness and not forgets the cultural roots they are in, Sundanese culture.

\section{References}

1. M. Matthew B. and A. M. Huberman, Data Kualitatif, Terjemahan Tjetjep Rohendy, (1992).

2. M. Lexy J., Metodologi Penelitian Kualitatif, Bandung, (2006).

3. A. C. Alwasilah, Pokoknya Kualitatif: Dasar-Dasar Merancang dan Melakukan Penelitian Kualitatif, (2008).

4. A. Maksum and L. Y. Ruhendi, Paradigma Pendidikan Universal, IRCSod, Yogyakarta, (2009).

5. A. Munadir, Strategi Sekolah dalam Pendidikan Multikultural, Jurnal Pendidikan Sekolah Dasar Vol. 2, (2016). 